\title{
Intersection of Native Characteristics Factors as a Feasibility of Teaching Factory Collaboration Program Between Companies and Vocational Schools in Extrusion Material for Lighting Product
}

\author{
Catur Kurniawan* \\ Prodi Teknik Mesin \\ Univarsitas Pamulang Tangerang Selatan \\ Banten, Indonesia \\ *dosen00578@unpam.ac.id
}

\author{
Haryantini \\ Prodi Manajemen \\ Univarsitas Pamulang Tangerang Selatan \\ Banten, Indonesia
}

\begin{abstract}
This study observes the native character factors of company institutions hereinafter referred to as DUDI (Business and Industry Field, eg. Company) and SMK (Vocational High School) using multivariate statistical factor analysis in the field of expertise in fabrication and assembly of extruded material products for the electricity-lighting industry. The research results reveal the formation of a construction component of intersection that becomes a feasibility space as a meeting point for critical and crucial discriminants which is the basis for the Teaching Factory (TEFA) collaboration. The factor variable involved in the intersection component is the Few Variant of Spare Part (VSS) in DUDI which correlates with the variable of the Human Resources (HR) factor in SMK. Meanwhile, the DUDI native character dichotomous construction component includes the Operational Work Environment (LKO) and General Frenchise Flexibility (FFU) factors. The dichotomous construction component of SMK native character is the Easy Acceptable Product (PMD) factor variable. The dichotomous construction contains a native factor variable which is an internal privacy that works to strengthen each institution and indirectly contributes to the feasibility of the intersection through its correlation to the factor variables that are members of the intersection construction. Ten other factor variables in this study are not explained, but can be considered as candidates who are still included in assessing the teaching factory cooperation.
\end{abstract}

Keywords-dichotomy construction, factor analysis, intersection construction, native characteristics, Teaching Factory

\section{INTRODUCTION}

This research on the topic of the topic of teaching factory, hereinafter referred to as TEFA, which has successfully brought technology from the industrial field fully implemented in technical vocational high schools. TEFA in the Government Regulation of the Republic of Indonesia Number 41 of 2015 concerning Industrial Resource Development is described as: "TEFA factory is a production facility that is operated based on actual working procedures and standards to produce products according to real conditions in the Business and Industry Field, e.g. Company (DUDI) and not profit-oriented. The general objective of the research is to get a generalization of the pattern of cooperation between SMK and industry in the TEFA learning pattern which will have a positive impact on improving cooperation (partnership) in a systematic and planned manner and based on a win-win solution position. The application of the TEFA learning pattern is a synchronization of the field of vocational education with the industrial field, so that there is a check and balance of the education process at SMK and / or tertiary institutions to maintain and maintain harmony (link and match) with the needs of the job market. This research has succeeded in achieving the above objectives by uncovering the constraints of the two poles of different institutional characters between DUDI and Schools by mapping them into three construction scenarios of factor variables as well as providing solutions to the problem so that this program is successfully implemented according to the Regulation of the Supervisory Board of the Directorate of Vocational High School Development No: 1156 / D5.3 / KU / 2019 regarding instructions for implementing TEFA government assistance.

\section{A. Related Work}

Currently, there is still a miss match between what is learned in school and the field of business and industry. This means that the learning materials at SMK are not in accordance with the needs of the field of work, so it is necessary to increase the quality, relevance and revitalization of vocational education in forming quality, highly competitive HR Thus a link and match is created between learning in schools and the needs of the business field / industrial field (DUDI) [1]. The real problems currently occurring in the implementation of vocational education can be identified based on two aspects, namely demand and supply. In the supply and demand aspect, 
the industry stated that the qualifications of graduates were not in accordance with DUDI's expectations, both in mastering hard skills (skills), soft skills (work ethic and independence), and communication skills. As for the supply aspect, institutions are faced with limited resources (facilities, human resources, finance) and the lack of involvement of the business / industrial field as users of graduates in vocational development, resulting in a gap between competencies developed in schools and industrial needs [1]. The concept of link and match competencies of SMK and DUDI in the Vocational Education Revitalization program is estimated to be able to sharpen the accuracy of fulfilling the labour supply-demand. The concept of link and match between educational institutions and the field of work is believed to be ideal in increasing quality vocational education graduates and reducing unemployment. The key to a successful link and match is the role of government and the collaboration between SMK and DUDI. One of them is the collaboration in the preparation of vocational learning programs that are directed at applicative teaching and focus more on the competence of certain fields of expertise with the aim that the resulting graduates are ready to enter the company. Ideally, learning activities should be based on the field of work with DUDI competencies in the form of direct experience or "hands on experience" of students [1].

Teaching factory teaching is a production / service-based learning concept in Vocational Schools that refers to the standards and procedures applicable in the industry, and is carried out in an atmosphere like what happens in the industry. This is in accordance with the characteristics of vocational education as mentioned by Herminarto Sofyan, et al. namely: (1) preparing students to enter the company; (2) based on the needs of the "demand-market-driven" field of work; (3) mastery of the competencies needed by the field of work; (4) student success in "hands on" or field work performance; (5) close relationship with the field of work; (6) responsive and anticipative to technological advances; (7) learning by doing and hands on experience; (8) requires greater investment and operational costs than general education [2]. The teaching factory concept is combining learning and a realistic work environment and creating relevant learning experiences. "Teaching factory concept as an approach that combines the learning and working environment from which realistic and relevant learning experiences arise" [3].

The basic principles of teaching factory in SMK in implementing the teaching factory program are: (1) There is an integration of work experience into the SMK curriculum; (2) All equipment and materials as well as educational actors are prepared and designed to carry out the production process with the aim of producing products (goods or services); (3) There is a combination of production-based learning and competency learning; (4) In production-based learning, vocational students must be directly involved in the production process, so that their competencies are built based on production needs. Production capacity and product types are the main keys to the success of implementing production-based learning [1].
The main components of the ecosystem in implementing the teaching factory are students, teachers, school management. The ideal conditions for implementing teaching factory in SMK, include aspects of learning, human resources, facilities, practical activities, cooperation networks, products and services, transparency of recording transactions, legal aspects. Important aspects in the teaching factory concept are competence, didactic, facilities / equipment, human resources, management, environment [1].

The targets of implementing teaching factory learning include: (1) Through teaching factory learning students have the opportunity to learn theory and practice at school with an atmosphere that is felt to resemble the atmosphere in an industrial work system. (2) The establishment of ongoing cooperation between schools and DUDI which is always supported and protected by the Ministry of Industry, the Ministry of Education and Culture, the Directorate of PSMK, the Industry Service and the local Education Service. (3) The teacher easily guides students to learn in fulfilling the KKM required as a graduation standard, guides students to be able to learn to work by following a block schedule that has been compiled, then students are able to carry out and complete work in the form of goods / services that have a level standardization of the company. (4). SMK graduates are not hesitant and awkward in working in the real industrial field so that the absorption rate of the company of SMK graduates in the industrial field will increase. (5) Schools in improving quality, fulfilment of sarpras and attainment of the vision and mission become easier to implement. (6). Constraints faced by the industry in recruiting qualified workers can be overcome and helped by SMK as partners [1].

Meanwhile, Dadang Hidayat Martawijaya [4] also developed a teaching factory model called the TF-6M Model. The model developed is implemented in students who take production subjects in the mechanical engineering department. The model developed is an effort to create an industrial atmosphere / atmosphere in practical activities at school. This effort is realized by changing management practices in schools to management of production activities as in companies.

\section{B. Our Contribution}

The specific objectives of this study are (1) To observe the dominant character factors of the DUDI and SMK institutions using a dichotomous analysis approach. (2) Furthermore, with multivariate statistical factor analysis, a character can be categorized as positive if it has a tendency to strengthen cooperation and negative if it has a tendency to weaken cooperation. (3) Describe the filtered factors in the slice and reinforce their character with reinforcement analysis until all indicators can be mapped. (4) Generalizing the results of the analysis into a general framework for implementing the teaching factory. The urgency of this research lies in the awareness of the introduction of dominant characteristic factors by the parties working together in TEFA as (1) starting lines to start cooperation with the hope of arriving at the finish line as expected. (2) A suitable slice of character between DUDI and 
SMK can be used as a stable meeting area where the movement of two parties will have a reinforcement and complementary effect or reinforcement and complementary content. (3) The general framework obtained can minimize the failure of cooperation. (4) This research will make the parties aware that if there is no slice of character as a necessary condition, then there is no reason for the parties to cooperate but first fulfil the sufficient requirements of each institution until the opportunity in the slice of characteristic factors exists.

Specific competence related to this research scheme are (1) The degree of difficulty of the DUDI work subcontracted to SMK through the TEFA program must be less than or equal to the ability of trained SMKs to do that job. (2) The duration of immediate mastery of DUDI work by SMK students must be less than or the same as the duration available in the school curriculum before the student completes the duration of his study. (3) Continuous change of operator personnel in a work station group, it is necessary to arrange multiple and parallel arrangements so that a work division is not completely replaced by new operators.

\section{Paper Structure}

The rest of the paper is organized as follows. Section 1 defines the parties who cooperate. Section 2 specifies the product object to work with. Section 3 specifies DUDI native variables and SMK native variables. Section 4 conducts a multivariate statistical analysis study to obtain the interpretation of the intersection of the correlation between variables as an intersection construct and a dichotomous construct.

\section{BACKGROUND}

\section{A. Gap between DUDI and SMK}

This research is motivated by the fact that to teaching and to studying are the basic native vocational schools in education. Meanwhile, to engagement factory to fulfill consumer needs is the basic native in the business and industrial field (DUDI). Furthermore, the effort to embedding the two institutions is called the Teaching Factory. This paper puts its hypothesis on the assumption that heterogeneity from two different field backgrounds will have a complementary function and produce the same direction of goals where each institution will take advantage from each other with positively and productive acceleration. Whereas the antithesis is that one heterogeneity against the other will lead to a different direction of purpose where the resultant is both mutually nullifying and counterproductive. The chances of acceptance of the hypothesis are great, if and only if those involved in the collaboration have realized and have recognized the positive native factors and negative native factors themselves and their partners. So this is an absolute prerequisite for building an optimal architectural scheme for cooperation programs. In terms of unemployment, it turns out that the largest TPT occurs in the population who graduated from Vocational High Schools (SMK), reaching $8.63 \%$.

\section{B. Research Variables}

The variables of native DUDI factors at PT VCP with the subject of fabrication and electric lamp assembly products known as the brand name Valex Folifix, are: V1. Simple Manufacturing Element (EMS), the number of locations and work station area required is small. The main machine at the fabrication location is a mitter saw that is positioned on a stable table. Furthermore, two drills are needed to make holes in the edge caps, while the main tool at the assembly site is only four screwdrivers. The rest of the manufacturing is only in the form of assembly tables and warehouse for storing raw materials and warehouse for storing finished goods. One production line team only consists of 5 people, consisting of 1 person at the mitter saw work station, 1 person at the drilling work station, 1 person at the assembly workstation, 1 person in the raw material supply warehouse and finished warehouse, 1 administrative worker orders and finance. V2. Fewer spare part (VSS) variants, only 5 main spare parts, but can be assembled into many product variants. V3. Installation Error Prevention (PKP), each spare part piece has a poka-yoke error prevention system and each spare part piece is cut using a standard stopper and a standard mall mold for the perforation process. V4. High Product Flexibility (FPT), each piece of raw material does not recognize residue nor does it recognize reject. The material can still be useful to the end because it is flexible and can be useful in the composition of other model variants. V5. Simple Product Operations (OPS), Valex folifix is designed to be easy to work with. The SOP is clear. V6. Sufficient Profit Sharing (SPC), For each level of Frenchise there is a clear and transparent profit scheme for each partner. V7. Operational Work Environment (LKO), DUDI's operational work environment is carried out by Make For Stock and Make to Order which is strict on quality standards and delivery time standards. V8. Flexibility General Frenchise (FFU), the level of frenchise allows cooperation partners of PT. VCP takes part or all of what is offered in accordance with its capabilities starting from: 1.Sockish, 2. Slicer, 3. Assembler, 4. Electric wiring, 4. Outlet, 5. Installer, 6. Services.

Variables of native vocational factors are taken from standard parameters according to the reference of the ministry of primary and vocational secondary education for the implementation of TEFA, namely: V9. Industrial Orientation Management (MOI), Financial Administration, Organizational Structure + Jobdes, Standard Operating, Performance Procedures and Workflow, Leadership, TEFA Impact on institutions and the environment. V10. Industrial Miniature Workshop (BMI), Equipment, Management of the use of MRC * tools, Layout workshop, K3 implementation. V11. Learning Patterns - Training (PPT), Learning Implementation Plans (RPP), and LKS (jobsheets), practical materials, practice bases, training implementation, entrepreneurship, teaching / instructor activities, corporate culture based. V12. Acceptable Products (PMD), Products / services for internal needs, market acceptance, Delivery, Quality, Quality control, Product innovation / diversification. V13. Human Resources (HR) (SDM), Competence of Teaching Factory, Amount and suitability of HR to run the Teaching Factory, Motivation, 
Innovation (benefits for "users"), Team work, Training for internal personnel. V14. Industrial and School Relations (HIS), Forms of cooperation, Project work, Technology transfer, Investment by industry. V15. Ready to Work Demands (TSK), Ready to work, Demand-Market-Driven, Competence mastery, Performance in DUDI, DUDI Relations Responsive to technological advances, Learning by doing and hands on experience, Investment and operational facilities.

\section{Data Collection and Processing}

The questionnaire contains in research questions have represent each factor variable. The questionnaire was given to 40 respondents in the form of multiple choice on a lickert scale in a row from numbers 1 to 5 indicating that the statements were very lacking, lacking, good enough, and very good. The collected data is shown in Table 1 . The results of the data normality test on the eight variables of the DUDI native factor and seven variables in the school's native factor using the OneSample Kolmogorov-Smirnov Test obtained general normal results because it is greater than or equal to 0.05 shown in Table 2. Based on the output of SPSS One -Sample Kolmogorov-Smirnov Test with all the results of the factor variables are normally distributed, then the next stage of data processing is factor analysis. Factor analysis is a technique used to look for factors that are able to explain the relationship or correlation between observed independent indicators. Factor analysis is a family of multivariate analysis which aims to summarize or reduce the overall observed variables into several new variables or dimensions, but the new variables or dimensions that are formed are still able to represent the main variables [5]. The output value of the Kaiser-Mayer-Olkin Measure of Sampling Adequacy (KMO-MSA) and the Bartlett's test are as shown in Table 3. The KMO value is $0.507>0.5$ and the Bartlett's test value is $0.016<0.050$ means that it can be continued to the step of getting a relationship (correlation) between variables through Anti Image Correlation Value From the Anti Image Correlation value table in Table 4, it is found that the factor variables that deserve to be considered in the teaching factory analysis are those with a value> 0.5 , so that the PKP, FPT, MOI, BMI, TSK variables are excluded. Meanwhile, from Table 5 (communality), variables with extraction value $<0.50$ cannot explain the factors, including OPS, and PPT.

TABLE I. RECAPITULATION OF THE RESPONDENTS' ANSWERS

\begin{tabular}{|c|c|c|c|c|c|c|c|c|c|c|c|c|c|c|c|}
\hline \multirow[t]{2}{*}{ Lickert } & \multicolumn{8}{|c|}{ Variable Factor DUDI (Company) } & \multicolumn{7}{|c|}{ Variable Factor SMK (Vocational) } \\
\hline & $E M S$ & VSS & $P K P$ & $F P T$ & OPS & $S P C$ & $L K O$ & $F F U$ & MOI & $B M I$ & $P P T$ & $P M D$ & $S D M$ & HIS & TSK \\
\hline 1 & 1 & 2 & 0 & 0 & 2 & 6 & 2 & 8 & 6 & 2 & 0 & 0 & 2 & 2 & 2 \\
\hline 2 & 6 & 2 & 7 & 7 & 7 & 13 & 5 & 13 & 12 & 4 & 7 & 6 & 5 & 11 & 5 \\
\hline 3 & 8 & 9 & 8 & 10 & 10 & 12 & 8 & 14 & 10 & 8 & 8 & 9 & 11 & 15 & 7 \\
\hline 4 & 12 & 12 & 11 & 8 & 8 & 9 & 11 & 4 & 9 & 11 & 11 & 12 & 8 & 10 & 11 \\
\hline 5 & 13 & 15 & 14 & 13 & 13 & 0 & 14 & 1 & 3 & 14 & 14 & 13 & 14 & 2 & 15 \\
\hline Resp & 40 & 40 & 40 & 40 & 40 & 40 & 40 & 40 & 40 & 40 & 40 & 40 & 40 & 40 & 40 \\
\hline
\end{tabular}

TABLE II. ONE-SAMPLE KOLMOGOROV-SMIRNOV TEST

\begin{tabular}{|c|c|c|c|c|c|c|c|c|c|c|c|c|c|c|c|c|}
\hline & & EMS & VSS & PKP & FPT & OPS & SPC & LKO & FFU & MOI & BMI & PPT & PMD & SDM & HIS & TSK \\
\hline \multicolumn{2}{|c|}{$\mathbf{N}$} & 40 & 40 & 40 & 40 & 40 & 40 & 40 & 40 & 40 & 40 & 40 & 40 & 40 & 40 & 40 \\
\hline \multirow{2}{*}{$\begin{array}{c}\text { Normal } \\
\text { Parameters } \\
\mathbf{a}, \mathbf{b}\end{array}$} & Mean & 3.75 & 3.90 & 3.80 & 3.75 & 3.58 & 2.60 & 3.75 & 2.43 & 2.78 & 3.83 & 3.80 & 3.80 & 3.68 & 2.98 & 3.80 \\
\hline & $\begin{array}{c}\text { Std. } \\
\text { Deviation }\end{array}$ & 1.149 & 1.128 & 1.114 & 1.104 & 1.259 & 1.008 & 1.214 & 1.010 & 1.187 & 1.196 & 1.114 & 1.067 & 1.228 & .974 & 1.224 \\
\hline \multirow{3}{*}{$\begin{array}{c}\text { Most } \\
\text { Extreme } \\
\text { Differences }\end{array}$} & Absolute & .211 & .210 & .209 & .196 & .196 & .199 & .207 & .190 & .193 & .212 & .209 & .199 & .210 & .190 & .215 \\
\hline & Positive & .138 & .165 & .141 & .152 & .151 & .199 & .152 & .188 & .193 & .163 & .141 & .148 & .159 & .190 & .163 \\
\hline & Negative & -.211 & -.210 & -.209 & -.196 & -.196 & -.179 & -.207 & -.190 & -.149 & -.212 & -.209 & -.199 & -.210 & -.185 & -.215 \\
\hline \multicolumn{2}{|c|}{ Kolmogorov-SmirnovZ } & 1.335 & 1.330 & 1.324 & 1.242 & 1.241 & 1.260 & 1.306 & 1.204 & 1.221 & 1.341 & 1.324 & 1.261 & 1.327 & 1.200 & 1.359 \\
\hline \multicolumn{2}{|c|}{ Asymp. Sig. (2-tailed) } & .057 & 0.58 & .060 & .092 & .084 & 0.84 & .066 & .110 & .101 & .055 & .060 & .083 & .059 & .112 & .050 \\
\hline
\end{tabular}

TABLE III _ KMO AND BARTLETT'S TEST

\begin{tabular}{|c|c|l|}
\hline Kaiser-Meyer-Olkin Measure of Sampling Adequacy & .507 \\
\hline $\begin{array}{c}\text { Bartlett's Test of } \\
\text { Sphericity }\end{array}$ & Approx. Chi-Square & 138.317 \\
\cline { 2 - 3 } & df & 105 \\
\cline { 2 - 3 } & Sig. & .016 \\
\hline
\end{tabular}


TABLE IV. ANTI-IMAGE MATRICES

\begin{tabular}{|c|c|c|c|c|c|c|c|c|c|c|c|c|c|c|c|c|}
\hline & & $E M S$ & VSS & $P K P$ & $F P T$ & OPS & $S P C$ & $L K O$ & $F F U$ & MOI & $B M I$ & $P P T$ & $P M D$ & $S D M$ & $H I S$ & $T S K$ \\
\hline \multirow{15}{*}{$\begin{array}{l}\text { Anti-image } \\
\text { Correlation }\end{array}$} & EMS & $.587^{\mathrm{a}}$ & .245 & -.159 & .102 & .100 & .137 & .231 & -.301 & 1.24 & .093 & .187 & .115 & .205 & .151 & -.141 \\
\hline & VSS & .245 & $.553^{\mathrm{a}}$ & -.039 & .123 & .111 & .014 & .073 & -.153 & -.340 & -.118 & -.237 & -.118 & -.376 & .114 & -.211 \\
\hline & $P K P$ & -.159 & -0.39 & $.382^{\mathrm{a}}$ & -.655 & -.112 & -.192 & -1.43 & -.279 & .135 & .090 & .082 & .057 & -.037 & -.181 & .418 \\
\hline & $F P T$ & -.102 & .123 & -.655 & $.426^{\mathrm{a}}$ & -.024 & .158 & .088 & .461 & -.268 & -.251 & -.051 & -.008 & .019 & .115 & -.288 \\
\hline & OPS & .100 & .111 & -.112 & -.024 & $.588^{\mathrm{a}}$ & .080 & .021 & -.312 & .096 & .037 & -.011 & -.038 & .051 & .200 & -.094 \\
\hline & $S P C$ & .137 & .014 & -1.92 & .158 & .080 & $.506^{\mathrm{a}}$ & .382 & .000 & .236 & -.107 & -.274 & -.047 & .001 & .290 & .219 \\
\hline & LKO & .231 & .073 & -.143 & .088 & .021 & .382 & $.610^{\mathrm{a}}$ & -.259 & $\begin{array}{l}.199 \\
\end{array}$ & $\begin{array}{l}-.090 \\
\end{array}$ & -.137 & -.153 & -.065 & -.029 & .024 \\
\hline & $F F U$ & -.301 & -.153 & -.279 & .461 & -.312 & .000 & -.259 & $.536^{\mathrm{a}}$ & -.171 & -.154 & .053 & .026 & -.112 & -.168 & -.202 \\
\hline & $M O I$ & -.124 & -.340 & .135 & $\begin{array}{l}-268 \\
\end{array}$ & .096 & .236 & .199 & -.171 & $.358^{\mathrm{a}}$ & .211 & -.001 & -.122 & .279 & .127 & .394 \\
\hline & $B M I$ & .093 & -.118 & .057 & -.251 & .037 & -.107 & -.090 & -.154 & .211 & $.481^{\mathrm{a}}$ & .079 & -.037 & .243 & .225 & -.010 \\
\hline & $P P T$ & .187 & -.237 & .082 & -.051 & -.011 & -.274 & -.137 & .053 & -.001 & .079 & $.554^{\mathrm{a}}$ & .188 & .164 & -.055 & -.025 \\
\hline & $P M D$ & .115 & -.118 & .057 & -.008 & -.038 & -.047 & -.153 & -026 & -.122 & -.037 & .188 & $.654^{\mathrm{a}}$ & -.146 & -.186 & -.267 \\
\hline & $S D M$ & .205 & -.376 & -.037 & .019 & .051 & .001 & -.065 & -.112 & .279 & .243 & .164 & -.146 & $.544^{\mathrm{a}}$ & .071 & .225 \\
\hline & HIS & .151 & .114 & -.181 & .115 & . 200 & .290 & -.029 & -.168 & .127 & .225 & -.055 & -.186 & .071 & $.555^{\mathrm{a}}$ & .206 \\
\hline & $T S K$ & -.141 & -.211 & .418 & -.288 & -.094 & .219 & .024 & -.202 & .394 & -.010 & -.025 & -.267 & .225 & .206 & $.461^{\mathrm{a}}$ \\
\hline
\end{tabular}

TABLE V. COMMUNALITIES

\begin{tabular}{|l|l|l|}
\hline & Initial & Extraction \\
\hline $\boldsymbol{E M S}$ & 1.000 & .650 \\
\hline $\boldsymbol{V S S}$ & 1.000 & .668 \\
\hline $\boldsymbol{P K P}$ & 1.000 & .840 \\
\hline $\boldsymbol{F P T}$ & 1.000 & .848 \\
\hline $\boldsymbol{O P S}$ & 1.000 & .451 \\
\hline $\boldsymbol{S P C}$ & 1.000 & .725 \\
\hline $\boldsymbol{L K \boldsymbol { O }}$ & 1.000 & .573 \\
\hline $\boldsymbol{F F U}$ & 1.000 & .641 \\
\hline $\boldsymbol{M O I}$ & 1.000 & .541 \\
\hline $\boldsymbol{B M I}$ & 1.000 & .574 \\
\hline $\boldsymbol{P P T}$ & 1.000 & .429 \\
\hline $\boldsymbol{P M D}$ & 1.000 & .528 \\
\hline $\boldsymbol{S D M}$ & 1.000 & .564 \\
\hline $\boldsymbol{H I S}$ & 1.000 & .594 \\
\hline $\boldsymbol{T S K}$ & 1.000 & .738 \\
\hline \multicolumn{3}{|c|}{ Extraction Method: Principal. }
\end{tabular}

Component: Analysis.

TABLE VI. ROTATED COMPONENT MATRIX

\begin{tabular}{|c|c|c|c|c|c|}
\hline & \multicolumn{5}{|c|}{ Component } \\
\hline & 1 & 2 & 3 & 4 & 5 \\
\hline$E M S$ & -.753 & .239 & .008 & .102 & -.119 \\
\hline$V S S$ & .785 & -.039 & .071 & .049 & -.205 \\
\hline$P K P(a i)$ & -.099 & .143 & -.165 & -.086 & .881 \\
\hline FPT (ai) & -.063 & -.408 & .386 & .069 & .724 \\
\hline$O P S(c)$ & -.093 & .577 & .282 & .108 & .135 \\
\hline SPC & .089 & -.051 & .112 & -.836 & .056 \\
\hline$L K O$ & .280 & .550 & -.138 & .401 & .112 \\
\hline $\boldsymbol{F F U}$ & .030 & .729 & -.168 & .244 & -.144 \\
\hline $\operatorname{MOI}(a i)$ & .278 & -.619 & -.117 & .218 & .140 \\
\hline BMI $(a i)$ & .041 & .132 & .728 & -.051 & .151 \\
\hline$P P T(c)$ & .411 & -.127 & .104 & -.481 & -.041 \\
\hline$P M D$ & .453 & .100 & .086 & .536 & -.136 \\
\hline$S D M$ & .595 & .278 & -.362 & -.034 & -.016 \\
\hline$H I S$ & .031 & .141 & -.679 & .298 & .152 \\
\hline TSK $(a i)$ & -.066 & .192 & .593 & .379 & -.449 \\
\hline
\end{tabular}

Extraction Method: Principal Component Analysis.

Rotation Method: Varimax with Kais er Normalization.

${ }^{\mathrm{a}}$ Rotation converged in 9 iterations.
In the column legend, in Table 6 , behind the factor variables are marked "ai" and "c" as anti-image matrices and communalities so that only five variables are included in the analysis, and only three component constructs can explain.

\section{CONCLUSION}

As statistical interpretation for multivariate variable factors refer to Table 6 it can be concluded that the Few Spare Part Variable (VSS) from DUDI has a strong correlation with Human Resources (HR) (SDM) at SMK in the construction component of the intersection between the two institutions to become a meeting point for opening the feasibility of Teaching Factory cooperation. Meanwhile, the Operational Work Environment (LKO) and General Frenchise Flexibility (FFU) are components of the dichotomous construction of the native character of DUDI, and Easy-to-Accept Products (PMD) are the dichotomous construction components of the native character of SMK. The dichotomous construction contains a native factor variable which is an internal privacy that works to strengthen each institution and indirectly contributes to the feasibility of the intersection through its correlation to the factor variables that are members of the intersection construction.

Specific competencies related to this research scheme are (1) The degree of difficulty of the DUDI job subcontracted to Vocational High Schools through the TEFA program must be less than or equal to the ability of trained SMKs to do the job. (2) The duration of immediate mastery of DUDI work by SMK students must be less or the same as the duration available in the school curriculum before the student in question completes the duration of his study. (3) Continuous change of operator personnel in a TEFA work station group needs to be arranged multiple and parallel so that a work division is not completely replaced by new operators. This competency is illustrated by DUDI's Few Spare Part Variable (VSS) factor which makes it easier for Human Resources (HR) at SMK to do it in a TEFA collaboration before students graduate within the available 
curriculum limits. In addition, the character of the DUDI dichotomous native factor in the Operational Work Environment (LKO) variable and the General Frenchise Flexibility Variable (FFU) corresponds to the character of the SMK Native dichotomous factor in the Acceptable Product (PMD) variable.

The researcher suggests that the Teaching Factory collaborators start a cooperative relationship from this meeting point. Ten other factor variables in this study are not explained yet at these research because of it has been represented with the communalities or anti image matrices, but how ever can be considered as candidates who are still included in assessing the teaching factory cooperation.

\section{ACKNOWLEDGMENT}

This research was supported by PDP (Beginner Lecturer Research) Directorate of Research and Community Service, Directorate General of Research and Development, Ministry of Research, Technology and Higher Education in 2020. Excelent participation has been given by respondents from vocational high school academics (SMK) around the city of Bogor, Depok and Tangerang. Warm reception by PT. VCP at the Work Shop in the science and technopark area of UNPAM III, South Tangerang city, Indonesia. The cooperation and support of the volunteers on this research was also very helpful.

\section{REFERENCES}

[1] Sanggam, dkk., Tatakelola Pelaksanaan Teaching Factory. Jakarta: Direktorat Pembinaan Sekolah Menengah Kejuruan, 2017.

[2] H. Sofyan, Pardjono, I.W. Djatmiko, and P Sudira, "Paradigma Baru Pendidikan Vokasi," [Online]. Retrieved from: http://staff.uny.ac.id/sites/default/files/pengabdian/prof-drherminartosofyan-mpd/paradig ma-baru-dan-guru-pendidikan-rev1.pdf

[3] Nayang Polytechnic, "Teaching factory concept," 2003. [Online]. Retrieved from: http://www.nyp.edu.sg/seg/innovative-teaching-nlearning/the-teachingfactory-concept [Accessed on: 14 February 2013].

[4] D.H. Martawijaya, "Developing a teaching factory learning model to improve production competences among mechanical engineering students in a vocational senior high school," Journal of Technical Education and Training (JTET), vol. 4, no. 2, December 2012.

[5] I. Siswanto, Pelaksanaan Teaching Factory Untuk Meningkatkan Kompetensi dan Jiwa Kewirusahaan Siswa Sekolah Menengah Kejuruan. Penelitian Pendidikan Teknik. Yogyakarta: FT UNY, 2010. 